\title{
Criterion validity of the Key Question for screening at-risk alcohol use in primary healthcare*
}

\author{
Validade de critério da Questão-Chave para rastreamento \\ do uso de risco de álcool na atenção primária \\ Validez de criterio de la Pregunta Clave para rastreo del consumo \\ arriesgado del alcohol en la atención primaria
}

How to cite this article:

Maciel MED, Vargas D. Criterion validity of the Key Question for screening at-risk alcohol use in primary healthcare. Rev Esc Enferm USP. 2020;54:e03553. DOI: http://dx.doi.org/10.1590/S1980-220X2018032503553

\section{Marjorie Ester Dias Maciel ${ }^{1}$ \\ Divane de Vargas ${ }^{2}$}

* Extracted from the thesis: "Tradução, adaptação cultural e validação da questão-chave para rastreamento do uso de risco de álcool para o português”, Escola de Enfermagem, Universidade de São Paulo, 2017.

${ }^{1}$ Universidade de São Paulo, Escola de Enfermagem, Programa de Pós-Graduação em Enfermagem, São Paulo, SP, Brazil.

${ }^{2}$ Universidade de São Paulo, Escola de Enfermagem, Departamento de Enfermagem Materno-Infantil e Psiquiátrica, São Paulo, SP, Brazil.
Corresponding author:

Marjorie Ester Dias Maciel

Av. Dr. Enéas de Carvalho Aguiar, 419

CEP 05403-000 - São Paulo, SP, Brazil

marjorieester@yahoo.com.br

\begin{abstract}
Objective: To perform criterion validation of the Key Question in Portuguese for screening at-risk alcohol use among users of Primary Healthcare services. Method: This is a psychometric study conducted with users of a Primary Healthcare service located in the city of São Paulo, Brazil. Participants responded to the Key Question which was applied in conjunction with the Alcohol Use Disorders Identification Test-C for concurrent validation and measurement of psychometric properties. Results: The sample consisted of 518 users. The Key Question presented 59\% specificity and 99\% sensitivity with respect to the Alcohol Use Disorders Identification Test-C in the general population. The accuracy was $81 \%$ in relation to this instrument. There was no influence of sociodemographic variables such as gender on the psychometric properties of the Key Question. Conclusion: The results indicate that the Key Question in Portuguese presented satisfactory psychometric qualities and suggest that its Portuguese version is as efficient for screening at-risk alcohol use as its reference standard, which subsidizes its use in Primary Healthcare.
\end{abstract}

\section{DESCRIPTORS}

Primary Health Care; Alcohol-Related Disorders; Validation Studies; Mass Screening; Primary Care Nursing. 


\section{INTRODUCTION}

Harmful alcohol consumption as well as its related problems are very prevalent in the Brazilian population ${ }^{(1-2)}$. Data from the Global Status Report show that alcohol affects $8.2 \%$ of males in Brazil, causing some type of morbidity, and that this percentage reaches $3.2 \%$ in females ${ }^{(2)}$.

Research has shown that individuals who drink excessive alcohol tend to use the Primary Healthcare (PHC) services twice more than other people ${ }^{(3)}$. It is estimated that from $7 \%$ to $20 \%$ of PHC services worldwide are used by those who drink harmful amounts of alcohol ${ }^{(3-4)}$, constituting a considerable percentage that should not be overlooked.

Therefore, it is justified to routinely investigate the alcohol usage pattern in this environment by health professionals in order to provide early detection and timely intervention in this portion of $\mathrm{PHC}$ users ${ }^{(4)}$; a measure which is consistent with the primary scope of $\mathrm{PHC}$, prevention and health promotion ${ }^{(5)}$. In addition, scientific evidence shows that screening for at-risk alcohol use followed by timely $\mathrm{PHC}$ intervention is effective in reducing the population's alcohol consumption level ${ }^{(6)}$.

For this reason, the strategy known as SBIRT (Screening, Brief Intervention, and Referral to Treatment) ${ }^{(7)}$ to identify at-risk alcohol use early has been increasingly used in PHC services in different countries ${ }^{(7)}$. However, despite the undeniable importance of this strategy, there are difficulties to implement it in PHC of the Unified Health System in Brazil $^{(5,7)}$.

These difficulties are conditioned by the existence of barriers, such as: professional unpreparedness to identify early and perform brief intervention in heavy drinkers, even occasionally ${ }^{(5)}$; lack of time in the work routine to assess the alcohol usage pattern in patients ${ }^{(6)}$; underestimating the harmfulness of excessive alcohol use ${ }^{(6)}$; and the lack of a standardized screening instrument to identify at-risk consumption, which is practical, brief, does not require specific training or knowledge for its use, which considers the differences in dosage levels for at-risk use between genders ${ }^{(7)}$, which may be used in the general population, and which requires little professional time to apply and interpret the results ${ }^{(7)}$.

There are currently some instruments available and validated for this purpose in Brazil, but which do not meet all the characteristics mentioned above in a single instrument, despite having reliable psychometric aspects. Some instruments have an excessive number of questions, which requires more consultation time for their application and costs with the production of materials ${ }^{(8)}$; they do not take gender differences into account when establishing equal risk dose parameters for both men and women ${ }^{(9)}$; they are restricted to specific populations ${ }^{(10-11)}$; and finally they are not sensitive to evaluate the at-risk use, only the later stages of alcohol-related disorders ${ }^{(12-13)}$, and are therefore not indicated for use in PHC.

In addition, these instruments require professionals to master their scoring classifications to identify and interpret which alcohol consumption pattern the respondent classifies into ${ }^{(9,13)}$, which may cause resistance and discouragement on the part of professionals to implement them in the health service.

Considering these barriers, it is justified that there should be a tool which can be implemented as an alternative to those that already exist, which is able to accurately identify at-risk alcohol use, which is low cost and can be employed by generalist health professionals, with agility in interpreting the results and having low training requirements. Instruments with these characteristics have the potential to stimulate their use in PHC services ${ }^{(5)}$.

In view of these aspects, the National Institute on Alcohol Abuse and Alcoholism (NIAAA) ${ }^{(14)}$ advocated screening alcohol use in 2005 with the use of a single question, appropriately named the Single-Question (SQ), for all people attending health services in that country who reported drinking alcohol by answering the pre-screening question "Do you drink alcoholic beverages?".

The proposal to use a single question to screen alcohol consumption was first implemented in a study conducted in $1997^{(15)}$, with the question "Have you ever had a drinking problem?”. Since then, several versions of a single question for screening alcohol use have been proposed. Among these, the one recommended by the NIAAA (2005) is called the Single-Question, which is "How many times in the past year did you have $\mathrm{X}$ or more drinks in a day?", where the value of $X$ is 5 for men and 4 for women, constituting at-risk use parameters by gender set by the World Health Organization $^{(3)}$. Screening is considered positive when the answer is one or more times ${ }^{(14)}$.

A group of researchers performed a Single-Question criteria validation for use in United States PHC services in 2009 , which showed good psychometric properties ${ }^{(16)}$. Thus, the authors suggested the need for validation studies and the use of the Single-Question in other languages in order to implement screening of at-risk alcohol use in populations from other parts of the world ${ }^{(16)}$.

Thus, the Single-Question was translated into Portuguese and culturally adapted in Brazil, being called the "Key Question" (Questão-Chave-QC) $)^{(8)}$. Considering that the criterion validity evidence of the Key Question in Portuguese has not yet been tested, this study aims to validate the criteria of the Key Question in Portuguese for screening at-risk alcohol use among users of primary healthcare services.

\section{METHOD}

\section{STUdY DESIGN}

This is a psychometric validation study of the Key Question $(Q C)$ criterion $^{(8)}$. Criterion validity can be defined as the correlation between the measure to be tested and a pre-established external criterion measure ${ }^{(17)}$. Thus, the tested instrument must be able to predict its criterion measure to be considered valid ${ }^{(18)}$. In this way, the performance of the instrument to be validated is compared with the performance of an instrument previously defined by the evaluator - called the reference standard or external criterion ${ }^{(18)}$. 
The study was conducted in the city of São Paulo in a Basic Health Unit (BHU) located in the SéHealth District.

\section{Population}

A total of 910 people were approached; 67 of them refused to participate in the study, 51 were excluded because they did not completely answer the questionnaire, and 274 were excluded because they said they did not drink alcohol. Therefore, 518 individuals remained in the final sample.

Inclusion criterion for the sample was being aged 18 years or older. Exclusion criteria included: (a) having some cognitive limitation; (b) stating they do not drink alcohol; (c) not completely responding to the data collection instrument; (d) being under the visible effect of illicit or intoxicating drugs as observed through alcohol breath, staggering gait, red eyes and/or alterations or psychomotor agitation at the time of data collection.

\section{Data collection}

Data were collected between January and June 2015 in the two working shifts of the unit (morning and afternoon) by four team nurses of the Center for Studies and Research in Nursing and Additions - alcohol and other drugs (NEPEAA), from the São Paulo School of Nursing. All interviewers were previously trained to avoid bias in applying and interpreting responses.

The approached subjects who agreed to participate in the study accompanied the researcher to a private room provided by the unit's management. Participants initially answered the pre-screening question recommended by the NIAAA $(2005)^{(14)}$ : "Do you drink alcohol?". If an affirmative response was given, the key question "How many times in the last twelve months have you had $\mathrm{X}$ or more drinks in one day?", the standard reference instrument (AUDIT-C) and the sociodemographic questionnaire (gender, age, marital status, education, religion and self-declared skin color) were then presented to the participant.

In order to standardize understanding by the lay population of what is a standard dose of alcoholic beverage, an insert was presented together with the $Q C$ containing the most consumed alcoholic beverages by Brazilians (beer, cachaça (Brazilian rum), vodka, wine, whiskey, liquor and draft beer), equivalent to a standard dose of alcohol (8 to 13 grams of pure alcohol) in $\mathrm{ml}$ as marketed or served (large bottle, bottle, mug, can, glass, etc.), as proposed by the World Health Organization (available for consultation on the institution's website) ${ }^{(19)}$, and adapted to the Brazilian reality by the National Institute of Science and Technology for Research on Alcohol and Other Drugs (available on the institution's website) ${ }^{(20)}$. The average data collection time was 35 minutes.

\section{Procedure}

The same methodological and statistical procedures used to validate the Single-Question in the PHC services of the United States of America ${ }^{(16)}$, as described below, were adopted to validate the instrument criterion in the Portuguese version in the Brazilian PHC services.

The $Q C$ was applied after adaptation and content validation, with the final Portuguese version being presented as: "How many times in the last 12 months have you drunk $\mathrm{X}$ or more doses of alcohol in 1 day?" ${ }^{(8)}$, where $\mathrm{X}$ is 5 for men and 4 for women. According to the parameters for at-risk alcohol use, screening is considered positive when the response is 1 or more times ${ }^{(14)}$.

In conjunction with the $Q C$, the Alcohol Use Disorders Identification Test-C (AUDIT-C) was used as a reference standard for concurrent validation as used in the baseline study $^{(16)}$. AUDIT-C refers to one of the shortened versions of AUDIT, consisting of the first three items of this instrument. Screening with AUDIT-C is considered positive from a score of 4 . This version presented $90 \%$ sensitivity and $83 \%$ specificity in a Brazilian study, being considered satisfactory to screen at-risk alcohol use ${ }^{(21)}$.

A questionnaire with sociodemographic information (gender, age, marital status, education, religion and self-declared skin color) was used in addition to these instruments.

\section{SAMPLE CALCULATION}

The calculation of the minimum sample size was defined based on the use of the sample calculation formula for populations of undetermined size, but which had a characteristic or condition to be studied which was previously estimated or having a stipulated prevalence value ${ }^{(22)}$. This formula was calculated as follows:

$$
\mathbf{N}=Z^{2} \times \mathrm{p} \times(1-\mathrm{p}) \div \mathrm{E}^{2}
$$

According to the formula above, the final product has the value of $\mathrm{N}$, which means the minimum number of individuals to compose the sample; $Z$ is the critical value of the normal distribution which determines the confidence interval; $p$ is the expected proportion of the characteristic in the population (in this case, harmful alcohol consumption, which includes at-risk, harmful use and likely dependence, according to the AUDIT classification), which was estimated at $22 \%{ }^{(23)}$; and $\mathrm{E}$ as the adopted sampling error margin $(5 \%) ;(1-p)$ is the percentage of characteristics other than the one which is wanted, and the value of $\mathrm{p}$ will vary between 0 and 1 . The adopted confidence interval was $95 \%$. Thus, the critical value of $Z$ was 1.96 and the adopted margin of error was $5 \%$. The $\mathrm{p}$-value was $0.22(22 \%)$.

Thus, replacing the items with the adopted indices gives:

$$
\begin{gathered}
\mathbf{N}=1.96^{2} \times 0.22 \times(1-0.22) \div 0.05^{2} \\
\mathbf{N}=3.8416 \times 0.22 \times 0.78 \div 0.0025=264
\end{gathered}
$$

Therefore, the minimum sample for this study in using this formula was estimated at 264 individuals. However, it was decided to add $25 \%$ of the minimum required size to the total sample in order to compensate for any sample losses due to incomplete questionnaires, thus ensuring sample power for all validation analyzes. As a result, the minimum sample required should consist of 330 people. 


\section{DATA ANALYSIS AND PROCESSING}

Data were double entered into a database and analyzed using the Statistical Package for Social Sciences (SPSS) for Windows, version 13.0.

Sociodemographic information was tabulated and presented as descriptive statistics by calculating the mean, standard deviation, relative and absolute frequencies. Psychometric properties were also calculated according to the sociodemographic characteristics of the research participants, given that the prevalence of a condition investigated in the population may affect the sensitivity and specificity of any screening test and that at-risk alcohol use is associated with certain sociodemographic characteristics such as gender ${ }^{(24)}$.

The AUDIT-C reference measurement instrument was applied together with the $Q C$ to analyze the validity evidence of its competing criterion. The correlation between the $Q C$ and AUDIT-C was calculated by the Pearson correlation coefficient to assess the evidence for convergent validity.

The properties of sensitivity, specificity, accuracy, positive likelihood ratio (PLR), negative likelihood ratio (NLR), negative predictive validity (NPV) and positive predictive validity (PPV) were calculated to analyze the evidence of predictive criterion validity. Sensitivity refers to the ability to identify true positive cases, with values ranging from 0 to $100 \%$; specificity can be defined as the ability to identify true negative cases and ranges from 0 to $100 \%{ }^{(18)}$. Both indices assess the test accuracy ${ }^{(22)}$.

Accuracy was calculated by checking the ratio of affirmative $Q C$ responses in relation to the AUDIT-C. PLR represents the probability that the test will assert the individual's true result after classifying it as positive, while NLR is the probability that the test will assert the individual's true result after classifying it as negative ${ }^{(22)}$. The probability of the $Q C$ to correctly classify people as negative or positive was calculated by negative predictive validity (NPV) and positive predictive validity (PPV).

One chose to calculate the psychometric properties for $Q C$ according to gender in this study because the $Q C$ has a difference in relation to the number of doses between genders, and there is evidence that this variable influences the values of these properties ${ }^{(24)}$.

The significance level adopted was $\mathrm{p} \leq 0.05$ with a $95 \%$ confidence interval (CI) for all statistical tests.

\section{ETHICAL ASPECTS}

This study was approved by the Ethics Committee of the Universidade de São Paulo School of Nursing, receiving opinion number $772.025 / 2015$. All those who agreed to participate signed the Informed Consent Form (ICF), which guarantees the confidentiality and anonymity of information in compliance with Resolution 466/2012 of the National Health Council involving Research with Human Beings.

\section{RESULTS}

A total of 518 people participated in the study, with a mean age of 44 years $(S D \pm 15)$. Regarding the socio-demographic profile, there was a predominance of males (58\%) with incomplete high school, single and self-declared as white, as shown in Table 1.

Table 1 - Sociodemographic information of BHU users - São Paulo, SP, Brazil, 2015.

\begin{tabular}{lcc}
\hline Variable & $\mathbf{9 5 \% \mathrm { Cl }}$ & $\mathbf{4 4}$ years \\
\hline Gender & $\mathrm{N}$ & \\
\hline Male & & \\
Female & 300 & 58 \\
\hline
\end{tabular}

\section{Education}

Incomp. elementary $\quad 8 \quad 1.2$

$\begin{array}{lll}\text { Comp. elementary } & 179 & 34.5\end{array}$

Incomplete High school $\quad 238$

Incomplete post-secondary $\quad 6 \quad 1.1$

$\begin{array}{lll}\text { Complete post-secondary } & 16 & 3.1\end{array}$

$\begin{array}{lll}\text { Post-graduation } & 71 & 13.7\end{array}$

\section{Civil status}

$\begin{array}{lll}\text { Married } & 179 & 34.5\end{array}$

$\begin{array}{lll}\text { Divorced/separated } & 63 & 12.2\end{array}$

Single $\quad 182 \quad 35.1$

In a stable relationship $\quad 94 \quad 18.2$

Self-declared color/race

$\begin{array}{lll}\text { White } & 213 & 41.1\end{array}$

Brown $\quad 160 \quad 31$

$\begin{array}{lll}\text { Black } & 118 & 22.7\end{array}$

$\begin{array}{lll}\text { Others (yellow/indigenous) } & 27 & 5.2\end{array}$

Note: $(\mathrm{N}=518)$.

Regarding the responses to the AUDIT-C, 284 (55\%) of the 518 participants were classified as positive for the pattern of at-risk alcohol use according to the classification of this instrument, and $206(72.5 \%)$ of this total were male, while 78 (27.5\%) were female, as shown in Table 2.

Regarding the $Q C$ classification, $376(72.5 \%)$ of the 518 users were classified as positive, and 237 (63\%) of these were male. The $Q C$ response pattern of the general population and by gender is also shown in Table 2 .

Table 2 - BHU user classification for at-risk alcohol use according to the AUDIT-C parameter and the Single-Question $(Q C)$ in the general population and by gender - São Paulo, SP, Brazil.

\begin{tabular}{lccc}
\hline $\begin{array}{l}\text { AUDIT-C } \\
\text { Classification }\end{array}$ & $\begin{array}{c}\text { General } \\
\text { Population (\%) }\end{array}$ & Male & Female \\
\hline Positive & $284(55 \%)$ & 206 & 78 \\
Negative & $234(45 \%)$ & 142 & 92 \\
\hline Total & $518(\mathbf{1 0 0} \%)$ & & \\
\hline QC Classification & & & \\
Positive & $76(72.5 \%)$ & 237 & 139 \\
Negative & $142(27.5 \%)$ & 63 & 79 \\
\hline Total & $518(\mathbf{1 0 0} \%)$ & & \\
\hline Note: female $(\mathrm{N}=218)$ and male $(\mathrm{N}=300)$. &
\end{tabular}

Sociodemographic variable properties were calculated according to these variables in order to ascertain whether any could influence the sensitivity and specificity values of 
the $Q C$, except gender (presented in a separate table), and according to the general population. The results are shown in Table 3.

Table 3 - Sensitivity and specificity indices of the $Q C$ in relation to the AUDIT-C in the general population and according to sociodemographic variables (except gender) of BHU users - São Paulo, SP, Brazil, 2015.

\begin{tabular}{lcc}
\hline \multirow{2}{*}{ General population } & Sensitivity* & Specificity* \\
\cline { 2 - 3 } Variable & $\mathbf{9 9 \% ( 9 7 \% , \mathbf { 1 0 0 } \% )}$ & $\mathbf{5 9 \% ( 5 3 \% , 6 6 \% )}$ \\
Civil status & $98 \%(94 \%, 100 \%)$ & $68 \%(58 \%, 77 \%)$ \\
Education level & $100 \%(93 \%, 100 \%)$ & $68 \%(56 \%, 79 \%)$ \\
Self-declared color/race & $99 \%(94 \%, 100 \%)$ & $70 \%(58 \%, 81 \%)$ \\
Occupation & $99 \%(95 \%, 100 \%)$ & $54 \%(44 \%, 64 \%)$ \\
Religion & $99 \%(95 \%, 100 \%)$ & $62 \%(52 \%, 70 \%)$ \\
No religion & $100 \%(91 \%, 100 \%)$ & $54 \%(40 \%, 67 \%)$ \\
\hline
\end{tabular}

${ }^{*} \mathrm{Cl}$ : $95 \%$.

Note: $(\mathrm{N}=518)$.

Table 3 shows that there were no significant changes in sensitivity and specificity values due to sociodemographic characteristics.

The psychometric properties regarding the predictive validity of the $Q C$ in relation to the AUDIT-C in the general population and according to gender are presented in Table 4.

Table 4 - Psychometric properties of the $Q C$ relative to the AUDIT-C in the general BHU user population - São Paulo, SP, Brazil.

\begin{tabular}{lccc}
\hline QC & $\begin{array}{c}\text { General } \\
\text { population (\%) }\end{array}$ & Male & Female \\
\hline Sensitivity* & $99 \%(97 \%, 100 \%)$ & $100 \%(97 \%, 100 \%)$ & $97 \%(93 \%, 99 \%)$ \\
Specificity* & $59 \%(53 \%, 66 \%)$ & $58 \%(48 \%, 68 \%)$ & $60 \%(51 \%, 69 \%)$ \\
PPV* & $75 \%(70 \%, 79 \%)$ & $81 \%(75 \%, 86 \%)$ & $64 \%(55 \%, 72 \%)$ \\
NPV* & $98 \%(94 \%, 100 \%)$ & $100 \%(92 \%, 100 \%)$ & $96 \%(89 \%, 99 \%)$ \\
PLR* & $2.44(2.09,2.85)$ & $2.4(1.92,3.00)$ & $2.44(1.96,3.03)$ \\
NLR* & $0.02(0.01,0.06)$ & $0(0.00,0.00)$ & $0.05(0.02,0.17)$ \\
\hline${ }^{*}$ Cl: $95 \%$. & & &
\end{tabular}

Note: $(\mathrm{N}=518)$. According to gender: female $(\mathrm{N}=218)$ and male $(\mathrm{N}=300)$.

As can be observed, the $Q C$ had higher sensitivity than specificity for males. The same situation occurred in females, but the specificity of the $Q C$ was slightly higher in females than in males.

The $Q C$ showed good accuracy (81\%) and good correlation with the AUDIT-C, obtaining a value of 0.914 in the Pearson coefficient $(p$-value $=0.015)$, thus being statistically significant.

\section{DISCUSSION}

This study sought to gather evidence of the validity of the $Q C$ criterion for screening at-risk alcohol use employing the AUDIT-C instrument as a reference standard as it had been performed in a study in the United States ${ }^{(16)}$.

A high positive screening index was observed by both the AUDIT-C and QC. This finding is related to the fact that most of the sample (58\%) was male, as it is well known that men consume alcohol at higher levels than women for various reasons, mainly cultural ${ }^{(24)}$, even among men attending the Brazilian PHC service ${ }^{(25)}$.

The study's own design in defining people who previously stated to consume alcohol as a selection criterion for the sample may have excluded a large number of women, since women traditionally tend to attend BHUs more frequently than men ${ }^{(25)}$ and usually abstain or consume alcohol to a lesser extent than males ${ }^{(24)}$. Thus, it is postulated that women approached for this study may have been excluded from the study because they stated that they did not consume alcohol.

In comparing the two instruments, the $Q C$ screened more individuals who were positive for at-risk alcohol use than the AUDIT-C. Two hypotheses are considered for this fact; the first assumes that subjects screened as negative on the AUDIT-C probably answered question number 3 on this instrument ("How often do you drink six or more doses of alcohol at once?) with the second answer option which was "at least once a month or less" and yet, depending on the answers to the previous items, the respondent may still be classified as negative for at-risk consumption. However, it may mean that a person who was usually a low-risk drinker had at least one episode of at-risk behavior at some point, which may be an isolated fact, and which is referred to in the literature as episodic heavy drinking ${ }^{(26)}$. However, this fact is not uncommon in Brazilian culture given that people tend to drink alcohol above their usual pattern on certain festive dates in the country, such as Christmas celebrations, Carnival and the end of sports championships, practicing episodic heavy consumption ${ }^{(26)}$. However, screening is considered positive for the $Q C$ for the one time that alcohol is consumed at an at-risk level, and a brief intervention is recommended.

The second hypothesis is that the $Q C$ considers different numbers of alcohol doses for men and women as the threshold between at-risk and low-risk drinking. Thus, the $Q C$ ranks a higher number of women with at-risk drinking patterns than the AUDIT-C, since the latter establishes equal limit dosage parameters for moderate drinking between genders.

The $Q C$ presented high sensitivity (99\%) in the general population, being more sensitive than the AUDIT-C (90\%) when it was tested in a sample from a Brazilian outpatient service $^{(21)}$. The $Q C$ was also more sensitive than its original English version $(81.8 \%)^{(16)}$, which may be related to cultural and idiomatic differences between the two countries ${ }^{(17)}$. The sensitivity and specificity of the $Q C$ did not statistically significantly change due to the sociodemographic characteristics of the sample.

The specificity of the $Q C(59 \%)$ was lower than its English version $(79.3 \%)^{(16)}$, however, remaining satisfactory from the point of view of the literature ${ }^{(17)}$. This means that the $Q C$ has a high chance of screening a true negative when an individual is screened as negative.

Thus, the other psychometric properties in this context (NPV, PPV, PLR, NLR), called post-test properties ${ }^{(17)}$, corroborate this fact, since the high NPV of the $Q C(98 \%)$ in the general population indicates a high probability that the screening result is true negative; and when considering only 
males, the value reaches $100 \%$ accuracy. Regarding PLR, values greater than 1 indicate how good the test is ${ }^{(22)}$; the opposite is true for NLR, meaning that the closer to zero its value, the better the test ${ }^{(22)}$, which was a fact that occurred with the $Q C$, reinforcing its suitability for screening for at-risk alcohol use. Thus, the $O C$ criterion validation showed good NPV, PPV, PLR, NLR, sensitivity and specificity values.

Considering that women are increasingly consuming alcohol $^{(20)}$, thus increasing their propensity to be considered at-risk, the $Q C$ has an advantage over other validated screening instruments in Brazil, as it considers different numbers of doses for men and women. Therefore, the $Q C$ can screen more women than the other instruments which have the same number of low-consumption dose intake limits for women as the number of doses for men.

The strong correlation between the $Q C$ and its reference standard was confirmed by statistical tests which indicated good accuracy $(81 \%)$ and the high value obtained for the Pearson coefficient (0.914), which is statistically significant in this study, as the literature reports high correlation for values from 0.90 to $1^{(22)}$.

A limitation in this study may have been due to the fact that the data collection period began in January, as affirmative responses to the $Q C$ may have occurred after the Christmas and New Year's festivities, in which people tend to drink alcohol excessively worldwide, thus constituting a context which may be questioned by some professionals in the area, who may not characterize this isolated episode as an at-risk practice. However, it should be mentioned that a single episode of at-risk intake is enough to cause social damage such as car accident due to drunk drivers ${ }^{(7)}$.

Another limitation of the study may be associated with negative $Q C$ responses due to the memory bias of the survey respondents related to generalizing events to which every self-report instrument is subject ${ }^{(27)}$. Nevertheless, even self-reported or self-declared screening instruments are considered reliable in the literature ${ }^{(20)}$.

The $Q C$ was validated for the general adult population attending PHC services, but it was not used in other populations such as adolescents, a rural population, hospitalized people, indigenous peoples, quilombolas, or immigrants. Therefore, future studies are recommended for measuring its psychometric properties in these specific groups.

\section{CONCLUSION}

The procedures employed in this study suggest that the $Q C$ has criterion validity and is suitable for use in the context of Brazilian Primary Healthcare for screening at-risk alcohol use, as it gathers good evidence of concurrent and predictive criteria validity.

\section{RESUMO}

Objetivo: Realizar a validação de critério da questão-chave em português para rastreamento do uso de risco de álcool entre usuários dos serviços de Atenção Primária à Saúde. Método: Trata-se de um estudo psicométrico realizado com usuários de um serviço de Atenção Primária à Saúde localizado na cidade de São Paulo, Brasil. Os participantes responderam à questão-chave que foi aplicada em conjunto com o Alcohol Use Disorders Identification Test-C para a validação concorrente e a aferição das propriedades psicométricas. Resultados: A amostra foi composta de 518 usuários. A questão-chave apresentou especificidade de $59 \%$ e sensibilidade de $99 \%$ em relação ao Alcohol Use Disorders Identification Test- $C$ na população em geral. A acurácia foi de $81 \%$ em relação a esse instrumento. Não se observou influência de variáveis sociodemográficas, como sexo, por exemplo, nas propriedades psicométricas da questão-chave. Conclusão: Os resultados indicam que a questão-chave em português apresentou qualidades psicométricas satisfatórias e sugerem que sua versão em português seja tão eficiente para o rastreamento do uso de risco de álcool quanto seu padrão de referência, o que subsidia seu emprego na Atenção Primária à Saúde para o rastreamento do uso de risco de álcool.

\section{DESCRITORES}

Atenção Primária à Saúde; Transtornos Relacionados ao Uso de Álcool; Estudos de Validação; Programas de Rastreamento; Enfermagem de Atenção Primária.

\section{RESUMEN}

Objetivo: Llevar a cabo la validación de criterio de la pregunta clave en portugués para rastreo del consumo arriesgado del alcohol entre usuarios de los servicios de Atención Primaria de Salud. Método: Se trata de un estudio psicométrico llevado a cabo con usuarios de un servicio de Atención Primaria de Salud ubicado en la ciudad de São Paulo, Brasil. Los participantes respondieron a la pregunta clave que les fue aplicada en conjunto con el Alcohol Use Disorders Identification Test- $C$ para la validación concurrente y la verificación de las propiedades psicométricas. Resultados: La muestra estuvo compuesta de 518 adictos. La pregunta clave presentó especificidad del 59\% y sensibilidad del 99\% con relación al Alcohol Use Disorders Identification Test-C en la población en general. La precisión fue del $81 \%$ con relación a dicho instrumento. No se observó influencia de variables sociodemográficas, como sexo, por ejemplo, en las propiedades psicométricas de la pregunta clave. Conclusión: Los resultados señalan que la pregunta clave en portugués presentó calidades psicométricas satisfactorias y sugieren que su versión en portugués sea tan eficiente para el rastreo del consumo arriesgado del alcohol como su estándar de referencia, lo que subsidia su empleo en la Atención Primaria de Salud para el rastreo del consumo arriesgado del alcohol.

\section{DESCRIPTORES}

Atención Primaria de Salud; Trastornos Relacionados con Alcohol; Estudios de Validación; Tamizaje Masivo; Enfermería de Atención Primaria.

\section{REFERENCES}

1. World Health Organization. Global status report on alcohol and health [Internet]. Geneva: WHO; 2014 [cited 2018 June 16 ]. Available from: http://apps.who.int/iris/bitstream/10665/112736/1/9789240692763_eng.pdf 
2. Brasil. Ministério da Saúde; Secretaria de Vigilância em Saúde. Vigitel Brasil 2013: vigilância de fatores de risco e proteção para doenças crônicas por inquérito telefônico [Internet]. Brasília: MS; 2013 [citado 2018 jul. 16]. Disponível em: http://bvsms.saude.gov.br/bvs/ publicacoes/vigitel_brasil_2013.pdf

3. Mitchell AJ, Brid V, Rizzo M, Hussain S, Meader N. Accuracy of one or two simple questions to identify alcohol-use disorder in primary care: a meta-analysis. Br J Gen Pract. 2014;64(624):408-18.

4. Pereira MO, Anginoni BM, Ferreira NC, Oliveira MAF, Vargas D, Colvero LA. Efetividade da intervenção breve para o uso abusivo de álcool na atenção primária: revisão sistemática. Rev Bras Enferm [Internet]. 2013 [citado 2018 jul. 16];66(3):420-8. Disponível em: http://www. scielo.br/scielo.php?script=sci_arttext\&pid=S0034-71672013000300018\&lng=en

5. Taufick MLC, Evangelista LA, Silva M, Oliveira LCM. Alcohol consumption patterns among patients in primary health care and detection by health professionals. Rev Saúde Pública [Internet]. 2014 [cited 2018 July 24];30(2):427-32. Available from: http://www.scielo.br/scielo. php?script=sci_arttext\&pid=S0102311X2014000200427\&lng=en

6. Ronzani TM, Mota DCB, Souza ICW. Alcohol prevention within primary care in municipalities in the state of Minas Gerais, Southeastern Brazil. Rev Saúde Pública [Internet]. 2009 [cited 2018 July 24];43(1):51-61. Available from: http://www.scielo.br/scielo.php?script=sci_ar ttext\&pid=S003489102009000800009\&lng=en

7. Fontanella BJB, Demarzo MMP, Mello GA, Fortes SLCL. Os usuários de álcool, Atenção Primária à Saúde e o que é "perdido na tradução". Interface Comunic Saude Educ [Internet]. 2011 [citado 2018 jul. 16];15(37):573-85. Disponível em: http://www.scielo.br/pdf/icse/v15n37/aop1311.pdf

8. Maciel MED, Vargas, D. Cultural adaptation and content validation of the Single-Question for screening alcohol abuse. Rev Esc Enferm USP. 2017;51:e03292. DOI: http://dx.doi.org/10.1590/S1980-220X2016048703292

9. Hauck Filho N, Teixeira MAP. Funcionamento diferencial do item no Alcohol use Disorders Identification Test. Aval Psicol [Internet]. 2013 [citado 2018 jul. 23];12(1):19-25. Disponível em: http://pepsic.bvsalud.org/pdf/avp/v12n1/v12n1a04.pdf

10. Fabri CE, Furtado EF, Laprega MR. Alcohol consumption in pregnancy: performance of the Brazilian version of the questionnaire T-ACE. Rev Saúde Pública. 2007;41(6):979-84.

11. Kano MY, Santos MA, Pillon SC. Use of alcohol in the elderly: transcultural validation of the Michigan Alcoholism Screening Test - Geriatric Version (MAST-G). Rev Esc Enferm USP [Internet]. 2014 [cited 2018 July 20];48(4):648-56. Available from: http://www.scielo.br/scielo. php?script=sci_arttext\&pid=S0080-62342014000400649

12. Mansur J, Monteiro MG. Validation of the CAGE Alcoholism Screening test in a Brazilian psychiatric inpatient hospital setting. Braz J Med Biol Res. 1983;16(3):215-8.

13. Meneses-Gaya C, Crippa JAS, Zuardi AW, Loureiro SR, Hallak JE, Trzesniak C, et al. The fast alcohol screening test (FAST) is as good as the AUDIT to screen alcohol use disorders. Subst Use Misuse. 2010;45(10):1542-57.

14. National Institute on Alcohol Abuse and Alcoholism. Helping patient who drinks too much: a clinician's guide. Washington: NIAAA; 2005

15. Fleming MF, Barry KL, Manwell LB, Jhon K, London R. Brief physician advice for problem alcohol drinkers: a randomized controlled trial in community-based primary care practices. JAMA. 1997;277(13):1039-45.

16. Smith PC, Smith SM, Davies-Allensworth D, Saitz R. Primary care validation of a single-question alcohol screening test. J Gen Intern Med. 2009;24(7):783-8.

17. Guillemin F. Cross-cultural Adaptation and Validation of Health Status Measures. Scand J Rheumatol. 1995;24(2):61-3.

18. Pasquali L. Psychometrics. Rev Esc Enferm USP [Internet]. 2009 [cited 2018 July 13];43(n.spe):992-9. Available from: http://www.scielo. br/scielo.php?pid=S0080-62342009000500002\&script=sci_arttext\&tlng=en

19. World Health Organization. Self-help strategies for cutting down or stopping substance use: a guide. [Internet]. Geneva: WHO; 2010 [cited 2018 June 16]. Available from: https://apps.who.int/iris/bitstream/handle/10665/44322/9789241599405_eng.pdf?sequence=1

20. Laranjeira R, Madruga CS, Pinsky I, Caetano R, Ribeiro M, Mitsuhiro S. II Levantamento Nacional de Álcool e Drogas - Consumo de Álcool no Brasil: tendências entre 2006/2012 [Internet]. São Paulo: INPAD; 2013 [citado 2018 mar. 20]. Disponível em: http://inpad.org. br/wpcontent/uploads/2013/04/LENADALCOOLResultadosPreliminares.pdf

21. Meneses-Gaya C, Zuardi AW, Loureiro SR, Marques JMA, Crippa JA. Is the full version of the AUDIT really necessary? Study of the validity and internal construct of its abbreviated. Alcohol Clin Exp Res. 2010;34(8):1417-24.

22. Correa SMBB. Probabilidade e estatística. 2a . ed. Belo Horizonte: PUC Minas Virtual; 2006.

23. Vargas D, Bittencourt MN, Barroso LP. Padrões de consumo de álcool de usuários de serviços de Atenção Primária à Saúde. Cienc Saúde Coletiva [Internet]. 2014 [citado 2018 jul. 13];19(1):17-25. Disponível em: http://www.scielo.br/scielo.php?script=sci_arttext\&pid=S1413$81232014000100017 \& \operatorname{lng}=\mathrm{en}$

24. Fachini A, Furtado EF. Diferenças de gênero sobre expectativas do uso de álcool. Rev Psiquiatr Clín [Internet]. 2012 [cited 2018 July 20];39(2):68-73. Available from: http://www.scielo.br/scielo.php?script=sci_arttext\&pid=S010160832012000200005\&lng=en

25. Guibu IA, Moraes JCD, Guerra AA, Costa EA, Acurcio FDA, Costa KS, et al. Características principais dos usuários dos serviços de atenção primária à saúde no Brasil. Rev Saúde Pública. 2017;51(2):30-7.

26. Sanchez ZM. A prática de binge drinking entre jovens e o papel das promoções de bebidas alcoólicas: uma questão de saúde pública. Epidemiol Serv Saúde. 2017;26(1):195-8.

27. Kohlsodof M, Costa Junior AL. O autorrelato na pesquisa em psicologia da saúde: desafios metodológicos. Psicol Argum. 2009;27(57):131-9. 